\title{
POTENTIAL OF OVERLOOKED INDUSTRY HERITAGE IN HOREHRONIE REGION IN SLOVAKIA AND ITS REGENERATION
}

\author{
Veronika Aschenbrierová ${ }^{1}$
}

\begin{abstract}
The territory of Slovakia is rich in places with an ironworks history, which formed important urban and economic centers in the past. The valuable urban-architectural settlements emerged due to favorable geographical conditions, availability of forest and water resources. Currently, these important historical spots find themselves in the regions suffering from lack of job opportunities and low level of life quality. The research work deals with one of the most important 19th century's Slovak ironworks, its urban and architectural values in the setting, and regenerative activities involving development activities to preserve the constantly overlooked part of Horehronie's cultural heritage. This study aims to contribute to the knowledge about the ironwork complex, to present its current state and research, which has stimulated interest in the protection of so far degrading industrial heritage. The result of this work is to show potential of industrial heritage in regional development and tourism, which is an opportunity to strengthen the region identity, its competitiveness, as well as to the potential of industrial heritage in regional development and tourism, which is an opportunity to strengthen the region identity, its competitiveness, and improve the socio-economic conditions of its inhabitants.
\end{abstract}

UDC Classification: 711, DOI: https://doi.org/10.12955/pss.v2.195

Keywords: industry heritage - Coburg - rural - regeneration - development - tourism

\section{Introduction}

Industrial architecture is undoubtedly an important part of the cultural heritage in Slovakia. The territory of Slovakia formed an important part of iron production in the Kingdom of Hungary. Technical and technological progress during the 19th century brought the emergence of new production complexes. The territory of Slovakia has been the main ironworks area of Slovakia for centuries (Greschner et al., 1990), and this determines the importance of the solved locality of the Pohorela Ironworks complex in Slovakia. Thanks to industrial production, the territory of Horehronie prospered in the past and is currently experiencing a decline. Since the cessation of production almost 100 years ago, there have been no revitalization interventions. The poor socio-economic status is significantly lower than in the whole territory of Slovakia. The region has long been dominated by fewer job opportunities, lower incomes, and the outflow of skilled people. The Banská Bystrica self-governing region aims to correct and reduce these disparities. Its integrated territorial strategy defined the region's potential for future development (Banskobystrický samosprávny kraj, 2021. It is important to start not only the preservation of the monuments of this once economically prosperous period, but also to improve the living standards of the population and the impact of social differences. The main aspect of this work is to verify the possibility of whether the revitalization of industrial monuments and the environment can at the same time contribute to the social and economic revitalization of the society of local residents, who find themselves on the margins of society. The other aspect is to contribute to the knowledge of the history and significance of the still overlooked part of cultural heritage - Pohorela complex, which supported the interest in protecting this important industrial heritage in the region and bring closer the participatory activities that have started a step-by-step activation process in most important locations along the route. In this article, the author presents examples of cultural routes from abroad to point out the importance of inclusion in international cultural and thematic routes and industrial historical sites. Other objectives include definitions of heritage, its administration and literature.

The work can serve as an inspirational example of an approach for sites with a similar history and current state, despite the absence of archival or specialized knowledge. An occasion for the elaboration of the given topic was the low awareness of the history and importance of the ironworks complex in the region as one of the most important ironworks sites in Slovakia. It was also the number of historic buildings of industrial architecture in individual settlements along the route, their condition and the potential for revitalization and integration into the life of the region. By raising awareness of the history, values and potentials of possible use, the community's frequent prejudices against industrial architecture can be erased and involved in the society's development programs and help develop one of the less economically efficient regions in Slovakia.

\footnotetext{
${ }^{1}$ Slovak University of Technology in Bratislava, Institute of Management, Bratislava, Slovakia, veronika.aschen@gmail.com
} 


\section{Pohorela complex}

The history of the Pohorela Ironworks complex in Horehronie relates to the Coburg family. With the establishment of ironworks in this region contributed to a significant construction-technical and urbanization boom in this region. The Coburg family has supported the systematic application of modern technologies in their companies since the first half of the 19th century. The Pohorela (Coburg) ironworks complex consists of seven settlements along the upper course of the river Hron. The geographical conditions of the valley made it possible to make ideal use of the potential of the river's water flow and enough wood from the large-scale forests (Holec, 2010). The complex consists of the settlements Červená Skala, Zlatno, Val'kovňa, Švábolka, Nová Maša (Ferdinandova huta), Pohorelská Maša (Augustova huta) and Polomka-Hámor (Lujza huta) in the distance of $20 \mathrm{~km}$ long. These were gradually established with iron processing technology and increasing demands on production and products. The first blast furnace was built in Červená Skala in the second half of the 18th century by F. Koháry, and after the end of working, the more modern blast furnace Ferdinandova huta was built in the new locality of Nová Maša, also closer to the complex administration. In the meantime, the ownership of the complex and forests in the region passed under the administration of the Coburg family. Pohorelská Maša became the seat of the complex administration and the summer residence of the family. The Coburg family had a manor house with a large park, a roman catholic church in the neo-gothic style and later a private railway station right in the park. In the individual settlements, there were pits, sheet metal and iron rolling mills, a clinic or other objects of the ironworks colony connected to the production objects. The first most modern sheet metal rolling mill in Hungary was established in Švábolka. At the end of the 19th century, steel was also produced in Nová Maša using a Siemens-Martin furnace. Ironworks were awarded several times at industrial exhibitions (Šarudyová, 1989).

\section{Theoretical background}

The theoretical basis of the article is based on international conventions. The International Committee for the Conservation of the Industrial Heritage (TICCIH) defined industrial heritage as „remains of industrial culture which are of historical, technological, social, architectural or scientific value. These remains consist of buildings and machinery, workshops, mills and factories, mines and sites for processing and refining, warehouses and stores, places where energy is generated, transmitted and used, transport and all its infrastructure, as well as places used for social activities related to the industry such as housing, religious worship or education." It also specifies the importance of the social value of industrial heritage ,....as part of the record of the lives of ordinary men and women, and as such, it provides an important sense of identity. It is of technological and scientific value in the history of manufacturing, engineering, construction, and it may have considerable aesthetic value for the quality of its architecture, design or planning." (TICCIH, 2003; Fragner, 2013). Industrial heritage documents the industrial past, technological development (know-how) and social life. To create a significant part and identity of the territory, which contain tangible, intangible values as well as movable and immovable components. It reflects the coexistence of cultural and natural landscapes. (ICOMOS-TICCIH, 2011)

Industrial heritage is a generally internationally recognized socio-cultural and economic category, it is material evidence of the civilizational changes initiated and shaped by industrial production. (Králová, 2011). TICCIH (2011), in the Dublin Principles, mention it is important to support public and corporate awareness for industrial heritage to its successful conservation. It includes ,...presentation of their operations as well as the stories and intangible heritage associated with their history, machinery and industrial processes, industrial or city museums and interpretation centres, exhibitions, publications, websites, regional or transboundary itineraries..."

An important part of the values of industrial heritage is the values of the country. Industrial heritage has significantly influenced the image of the landscape, its silhouette and is an important part of it. The value of a country results from the natural arrangement and results of human activity, forming a whole. The values of the landscape include landscape image, landscape character, genius loci, landscape identity. (Jančura, 2005)

Oevermann and Mieg (2015) presented in their study other values of industrial heritage and their categorization according to where they manifest themselves - architecture, urbanism, heritage restoration. They consider authenticity, design, development, economic value, environmental value, aesthetics, heritage values, integrity, and vision the fundamental industrial heritage values. Other values 
mentioned are accessibility, character, appearance, re-use and sensitivity. Approaches to the protection of industrial heritage can be different. They depend on many factors that affect the decision-making, planning and protection process. Heritage regeneration goes hand in hand with planning policy, including spatial planning, protection, regulation, inscription and re-use.

Industrial buildings and areas are often not perceived as a component of the territory, which has cultural and historical values. Their protection, understanding as to the potential or value of the territory is low. Raising awareness and thus increasing the social acceptance of these areas as historical, cultural and aesthetic values of the area can contribute to its preservation and prevent its demolition. Industrial heritage is an important part of our history and the territory at the local, national, and international levels. It is a remnant of industrial activity that documents its activities, social life and technological development. (Mackovičová \& Král'ová, 2017)

The natural and cultural heritage is part of the territorial capital and forms the identity of the territory. This wealth offers unique opportunities for territorial development, and its inappropriate use can endanger territorial development. The protection and promotion of cultural and natural heritage and its use as capital is important for long-term sustainable development. At the same time, its use can bring new job opportunities and strengthen recreational functions (Územná agenda 2020, 2011).

Mackovičová (2018) also points to the growing need for the involvement of cultural and thus also industrial heritage: "It is perceived as a potential source for the development of the territory and tourism at the local, national and international level."

She states that good management of the protection of cultural heritage (industrial heritage) lies in its knowledge and understanding. The first phase of the process is about analyzing and defining the locality, history, function, and the broader context of the heritage with the territory. An essential part of heritage analysis is the identification of values - cultural, natural, economic. Another part of the process is the creation of a development policy, which concerns the identification of factors, needs and goals. It is necessary to identify problems and potentials of heritage, create a development policy and prepare plan management. This part forms the core of the strategy. The last phase is the management itself and its implementation and subsequent monitoring and review of the completed plan. Stakeholders (individuals, communities, owners, municipalities ...) play a significant role in the entire planning and decisionmaking process. They can make a significant contribution to identifying and understanding values and their significance. They can also help to better identify problems, perceive them, clarify interests and expectations from heritage protection Mackovičová, 2018)

The management of industrial heritage sites needs rethinking in the context of urban change. The transformation of sites involves two perspectives-heritage conservation and urban development planning (Oevermann and Mieg, 2015). They say ,...increasing demand for re-using industrial heritage sites as a driver of urban economic development."

Mackovičová (2018) further states in her work how territorial capital, which is tied to industrial heritage, can be used in different ways for different functions. It depends on the area itself, the design, the overall condition and many other factors affecting its use. Today, the trend is to use these spaces, at least in the short term, in the form of organizing various events (exhibitions, concerts, conferences, ...), before finding their long-term use. Another possible way of using territorial capital are educational routes. They are becoming an interesting and important educational element of industrial tourism. These thematic routes through industrial heritage serve as an additional service for tourism (Kudela \& Lednický, 2002). Tourism is one of the possibilities for re-use and protection of industrial heritage. It provides new opportunities for his new life and becomes an important basis for the development of tourism (Ćurčić et al., 2015). Tourism can bring new financial resources, social development, the development of trade and services and thus new job opportunities for the city and the country. It is a good opportunity to restore deprived spaces and increase the quality of life (EESC, 2005). Visiting the industrial heritage is becoming an alternative and attractive form of tourism. At present, its popularity is increasing among the public as well as experts. The demand for a visit to these premises is higher, regardless of the nature of the production of architecture. Despite the fact that Slovakia was an industrial power in the time of Hungary, this potential is not used (Stašáková \& Kulla, 2016).

\section{State of knowledge}

Although the history of cultural heritage in Horehronie is diverse, the region is dominated by the history 
of folk traditions and folklore. The topic of iron history in the region is generally given less attention. There is a generally weak awareness of the iron history in the local population in the region. It is completely unknown to the younger generation of the population. The unknown and overlooked objects along the entire route are very different from the villages, where the wooden log architecture of agricultural settlements, whose origin is of a different ethnological character, predominated. These settlements were established only for the equipment of ironworks and were outside the former settlements of Wallachian colonization, which began in the second half of the 15th century as Polomka, Šumiac, Telgárt villages (Alberty, 1982). Only local enthusiasts are familiar with the history of industrial history, even from a socio-historical point of view, or from the technological point of view of iron processing. Architectural and historical knowledge is absent, as the production objects were mostly completely broken down after producing, probably around 1928.

The only publication mapping ironworks sites in Slovakia is a publication by Šarudyová (1989). The author describes the locality of the Pohorela ironworks complex in detail, chronologically presenting a comprehensive picture of ironworks the development of ironworks in Horehronie but describes the individual production sites in terms of technical and technological aspects production and iron production in the course of the 19th century.

Until Belláková (2018), in her publication, observed the architectural and urban image of historical ironworks sites in Slovakia for the first time. In the individual chapters, she describes the specifics of how the technological progress of iron processing architecturally shaped the areas of iron production. In its comprehensive database of mapping and research also list the solved locality in Horehronie. Since her work offers the first cross-sectional view of historical ironworks in Slovakia, the Pohorela ironworks complex does not analyze in more detail. She also states that the literature on the architectural and urban development of historic ironworks in Slovakia is fragmentary and to a large extent, austere. The key starting point for knowledge were historical image documents - photographs, illustrations, and cadastral maps from the 2nd half of the 19th century. Belláková (2018) also mentions the lack of archival material about private ironworks. In the case of the Pohorela complex, the original plans and drawings of producing buildings together with information about the architect are completely abstaining. The Koháry-Coburg Fund in the State archives in Banská Bystrica has not yet been processed and is assumed to contain mainly an economic and accounting agenda. Often insensitive transformation and loss of the original architectural morphology on the buildings occurred gradually over the course of more than 80 years, also on the basis of insufficient legislative protection. The records of industrial heritage in Horehronie have not been updated at all since the 1970s. In recent years, the buildings in Horehronie (including the national cultural monument) have lost their original values and elements due to insufficient interest from the monument authority. At present, four buildings from the entire iron complex are registered on the national cultural monument list. At the same time, there are still discrepancies in the records regarding the accuracy of parcel numbers and the objects themselves, which Belláková (2018) also pointed out during the research. Only in the last two years is a new database being processed, which tries to record the state of industrial heritage in Slovakia in detail. Based on the mapped preserved architectural and historical values in the solved locality, there is the potential to be protected far more historical objects. These are mostly residential houses of the gambling colony, warehouses or water raceways. The individual settlements excel in terms of architecture and history and in terms of urban and compositional values; therefore, industrial heritage sites should also be more territorially protected. In such a case, the settlement of Nová Maša stands out, the revitalization of which was dealt with in the past by a diploma thesis prepared at the Faculty of Architecture of the Slovak University of Technology in Bratislava.

In most cases, these sites are located in the unique environment of national parks, which bring the industrial heritage the potential for tourism development. An inseparable part of the Pohorela ironworks complex is the natural, cultural heritage of the Low Tatras and Muranska planina national parks in which it lies. Stašáková and Kulla (2016) in their article, describe the importance of industrial heritage for the development of tourism in Slovakia, where they identified the region as an area with insufficient potential for tourism development.

According to them, the industrial monuments in this locality are doomed to extinction. Paradoxically, most industrial heritage monuments are located in the Banská Bystrica Region, which also includes Horehronie. They also further explain that technical monuments need to be integrated into the 
development of tourism as a new product - thematic routes to monuments.

The most famous sightseeing route of industrial heritage in Slovakia has become the "Slovak Mining Route" connecting mining towns and localities in Slovakia, which presents rich mining heritage. The aim of the route was to increase awareness of our industrial mining heritage and protect it and increase tourism in these regions. This route includes 7 regions, including Horehronie (Weis, 2007). Another important route is the "Slovak Iron Route", which connects the sites of former iron ore mining, production and processing of iron and other metals and is divided into three basic circuits divided on the basis of regions. This sightseeing route has become part of the Central European Railway (Mitteleuropäische Eisenstrasse MEES). The Slovak Iron Route, connected with industrial history, includes a part of Pohorela complex and provides informations about cast-iron crosses and cast-iron memorial situated in the Horehronie region. (Železna cesta, 2021). An important achievement from around the world is the IBA Emscher Park project (Die Internationale Bauaustellung Emscher Park), which aimed to develop tourism in the Ruhr area in conjunction with the extensive regeneration of a devastated industrial area. Institutions and bodies have supported this vision from the local government level to the initiative of the Federal Government of Germany and the European Union. The idea of a post-industrial journey through the Ruhr has developed into the EU-funded "European Route of Industrial Heritage (ERIH)" project. It is a network of Europe's most important industrial monuments. Regions, cities and places promoting industrial history as an attraction for tourism The system of this European industrial heritage route is based on 94 of Europe's most important industrial monuments, anchor points in 13 European countries, 19 regional routes in 8 European countries (Belgium, France, the Netherlands, Germany, Poland, Austria, Spain and the United Kingdom) and 13 European thematic routes (e.g. mining, manufacturing, energy, ...). ERIH connects a total of more than a thousand facilities in 43 regions of Europe. 12 sites in this project, including one located in Horehronie - Čierny Hron Forestry Railway. (Erih.net, 2021).

An example of a way and purpose of using heritage locally and regionally tourism connected with the history of the Industrial Revolution and perceived as one of the most valuable heritage sites of this kind in Europe is The Iron Bridge Gorge Site (Cudny, 2017). Where the first meeting on the protection of industrial heritage took place in 1973. The conference aimed to draw attention to the threat and demise of many factories (TICCIH, 2003).

\begin{tabular}{|c|c|c|c|}
\hline \multicolumn{4}{|c|}{ Figure 1: Swot zanalyze of the Pohorela ironworks complex and Horehronie region } \\
\hline strengths & Weaknesses & opportunities & threats \\
\hline $\begin{array}{c}\text { Traffic connection } \\
\text { Route I./66 }\end{array}$ & Civic amenities & Tourism development & $\begin{array}{l}\text { Loss of historical objects } \\
\text { and architectural values }\end{array}$ \\
\hline Flow of the villages & Unattractive village & $\begin{array}{l}\text { Raising awareness about } \\
\text { the industrial history }\end{array}$ & $\begin{array}{l}\text { Loss of authenticity due } \\
\text { to inappropriate access to } \\
\text { restoration }\end{array}$ \\
\hline Historical importance & $\begin{array}{c}\text { Ignorance of historical } \\
\text { value }\end{array}$ & $\begin{array}{l}\text { Strengthen identity of } \\
\text { region Horehronie }\end{array}$ & $\begin{array}{c}\text { Weak education about the } \\
\text { history }\end{array}$ \\
\hline Authentic state & Absence of archives data & $\begin{array}{l}\text { Attractivity of region } \\
\text { for businesses entities }\end{array}$ & $\begin{array}{c}\text { insufficient legislative } \\
\text { protection }\end{array}$ \\
\hline Property relations & $\begin{array}{c}\text { No professional } \\
\text { historical research }\end{array}$ & $\begin{array}{c}\text { Cooperation of local } \\
\text { governments }\end{array}$ & \\
\hline $\begin{array}{l}\text { Close to national parks } \\
\text { Muránska planina, Low } \\
\text { Tatras, Slovak Paradise }\end{array}$ & Not suitable rebuilding & $\begin{array}{l}\text { Connection to cycle } \\
\text { routes and walks }\end{array}$ & \\
\hline \multirow{2}{*}{$\begin{array}{c}\text { Král'ova Hol'a } \\
\text { Highest cycled point in } \\
\text { middle Europe } \\
\end{array}$} & Neglected care & Thematic events & \\
\hline & Weak railway transport & & \\
\hline
\end{tabular}

\section{Data and Methodology}

Research processing can be perceived on several levels. The main one is to examine the overall picture of the complex, its development and relative functional connections of individual settlements, comparison of the historical and current state, observation and recording of architectural morphology and similarities or differences with the architecture of other municipalities in the region. Another was the analysis and examination of urban and architectural values of the production center on the route - 
Nová Maša, which contains the most preserved historical buildings and elements forming a unified historical production area. Last is the knowledge of the residential and administrative center of the whole complex Pohorelská Maša together with its historical park. During the elaboration of the topic of the Pohorela ironworks complex, several research methods were used, including direct observation during field research as well as interviews with local residents and persons who are actively involved in the topic in the locality. Furthermore, there was a significant search of available literature and internet resources from the history of the industrial heritage of the locality, the values of industrial heritage, heritage protection, sustainable development and tourism, or research in the archives. The situation from the historical maps was then compared with the current cadastral maps, and the findings were further personally checked in the locality by our own field research and observation, recording the current state and construction changes. Although there are significant material remains of industrial heritage and listed buildings in the locality, no archaeological and historical research was carried out in the locality until 2020; therefore, the research was based only on our own analyzes. The Dublin Principles and the Industrial Heritage Charter already describe that identification, documentation, and research are essential steps in restoring and preserving industrial sites. "Researching and documenting industrial structures, sites, landscapes and the related machinery, equipment, records or intangible aspects is essential to their identification, conservation, and the appreciation of their heritage significance and value.“ (ICOMOS-TICCIH, 2011).

Consideration was given to comparing similar interventions and were looking for revitalization are good examples. However, where the results of the revitalization of industrial areas are favorable in the locality and region, such as the Ruhr in Germany or Dolní Vítkovice in Bohemia. They are significantly larger scale and have greater character and extend to a much larger area, with the fact that these industrial areas were adapted to the new function shortly after the end of production. No comparable example of small ironworks was found, where, after a similar time lag, production began with revitalization processes that brought improvements in the socio-economic area to the site.

The contribution of this work is that the solution area consists of the pieces and their small individual value we added to the revitalization and development process as a whole. An example of the location of Železniki in Slovenia, with ironworking heritage from the mid-14th to the early 20th century, shows how technical heritage's historical architecture can cultivate the environment. The protection of the monument began in 1941 here. In Selška valley is a blast furnace 21 - meters high where hand-forged nails were made. The furnace stands on the square located in the old part of Železniki along the river Selška Sora. In the direct vicinity of the blast furnace is the Železniki Museum nestled in the mighty two-storey ironworker's house, in which the rich technical heritage of Železniki is presented from 1969. Despite the fact that few manufacturing architectural objects, so the furnace itself, which is the only evidence of industrial production and is an important symbol of the region, creates opportunities for cultural and social events in the square near the furnace. The Iron Smelting Festival is held here every year. As conservation of one artifact - a blast furnace with the revitalization of the surrounding environment to the town, it intensified life in the locality and create opportunities for social and economic development (Muzej Železniki, 2018).

\section{The Results of activities in the region}

In addition to the activities of local enthusiasts and associations presenting the topic of iron history in Slovakia and the mentioned publication by Belláková (2018), the interest in protecting this industrial heritage was also supported by the diploma thesis of the revitalization of Ferdinand's huta in Nová Maša made in 2019 at the Faculty of Architecture of the Slovak University of Technology in Bratislava. The object of the ruin was entered in the list of national cultural monuments in the 50s of the 20th century, and its condition was last registered in 1972 as very bad with the need for reconstruction. The work aroused interest in the restoration of the ruin among the owner of the monument and the monument authority and stimulated the interest of the Banská Bystrica self-governing region itself. Thanks to the efforts of the owner and several volunteers, the very first archaeological and historical research were carried out in the locality. Furthermore, it is planned to preserve the monument, revitalize its surroundings, and involve it in life in the region. During 2019, the goal arose to create cooperation between the regional tourism organization and the regional development agency, local governments and other enthusiasts to support the idea of saving this overlooked cultural heritage. It held several initiation meetings presenting the importance and potential of this industrial heritage in the region, and in 2019 
the regional tourism organization, in cooperation with the Horehronie Museum and with the financial support of the Banská Bystrica self-governing region, initiated a comprehensive study of The Coburg Ironworks Route Across Horehronie as ideas cultural route and product for the development of tourism in the region (Kupec Architekti, 2019). The visions of perspectives brought by this project were taken by several entities, led by the regional tourism organization, local self-government or institutions of local museums. The study provides an overview of the current state of the preserved industrial, architectural heritage in individual localities, identifies specifically preserved objects of production and non-production character, remnants of production objects and connections to the existing transport and tourist and cycling network. It focuses in more detail on Pohorelská Maša - as the center of the route, which played the central management and representation function of the complex in the past. Work in three parts solves:

- mapping of sites of the whole complex,

- proposal for revitalization of the park in Pohorelská Maša,

- the concept of using the Coburg manor in Pohorelská Maša.

The study proposes the marking of the route with road information boards for visitors to the region along the main traffic route and identifies specific places for the placement of boards with detailed information about the history of the building. Comprehensive consideration is being given to connecting the center - Pohorelská Maša - with other localities on the route in terms of functionality and communication, following the development of tourism in two neighboring national parks. The individual places and objects with their proposed functions refer to the history of Coburg (educational park, Coburg Museum, Museum of Metallurgy), but also offer space for absent civic amenities (accommodation, gastronomy). They also create spaces for educational and cultural activities (creative workshops, outposts, craft workshops). This would create new job opportunities for local people and attract the public from the wider area to the region. The study creates a basic basis for gradual staged involvement in the development of Horehronie within tourism, a possible connection with the surrounding regions of Spiš and Gemer, with localities of business activities of the Coburg family (Aschenbrierová, 2020). Other important places of connection of this cultural route are in Predná Hora and Jelšava. Subsequently, thanks to this work, several presentations of The Coburg Ironworks Route project were made for stakeholders and the first pilot information tours along the route, which were accompanied by the initiators themselves. These brought a positive response and stimulated cooperation at the international level in Vienna and Coburg. The topic also attracted the attention of the Faculty of Economics of the Matej Bel University in Banská Bystrica. It became the basis for the elaboration of a diploma thesis in the field of tourism with a focus on management of cultural routes in Slovakia. Based on the identified elements, the author created a suitable business model of the cultural route of the Coburg Ironworks Route Across Horehronie. At the same time, the author supplemented her research with a method of sociological questioning in the form of a questionnaire, which significantly contributed to the current knowledge of the level of awareness and the relationship of local people to this industrial heritage. $25 \%$ of respondents expressed an interest in cooperating in the creation of a cultural route (Fil'ová, 2021).

The whole initiative has also aroused the interest of other owners of historic buildings along the route who are interested in participating in the project and the historic buildings they own or inhabit, restore and revitalize. As Fil'ová (2021) also states, communication between the creators and the public is important for improving the creation of the entire project. In 2021, the initiators of the idea with other volunteers founded the civic association "Coburg in Slovakia" and their own website coburgovci.sk, which will cover the entire project in several ways. The goals of this non-profit organization are to support the building of strategic partnerships and interest groups in the region, participation in saving this cultural heritage through finding financial resources, creating and implementing educational and advisory activities, increasing civic awareness and participation in Horehronie, Gemer and Spiš region. Furthermore, support for community organization and activities for the development of local communities, participation in reducing unemployment and improving the quality of life in the region, cooperation with local craftsmen and regional producers for thematic workshops in historical objects, cooperation with other national and international organizations and working in the field of protection and the restoration of historic industrial architecture. Organizing or participating in lectures and workshops in terms of spreading awareness about the history and importance of the cultural heritage of industrial architecture. An important milestone for preserving and visibility this overlooked industrial 
heritage is that it was included in the strategic planning document of the Banská Bystrica self-governing region in the integrated territorial strategy for 2021-2027 as a topic of financial support from the European Structural Funds. It will be an investment to achieve the greatest possible effect for the development of the territory. The topic of industrial heritage in Horehronie and its development in the field of tourism has been included in the list of key development areas (Banskobystrický samosprávny kraj, 2021).

\section{Conclusion}

Through the cooperation of several entities and institutions and participatory activities with the public and residents, the industrial architecture of the ironworks complex can contribute to strengthening the cultural and social identity of Horehronie. Systematic revitalization and presentation have the prerequisites to contribute to the competitiveness of the region and support its social and economic development.

The aim of the work was to show how the Coburg ironworks route may contribute by raising awareness of the industrial history in the region and the values of the industrial heritage. By pointing out the potentials of possible economic use and thinking about involvement in the development of tourism, the frequent prejudices of the society against this group of cultural heritage can be erased. Despite the lack of archival and professional knowledge, years of overlooked industrial heritage may be integrated into life in the region and may have a significant influence on the local development. By raising awareness of the history, values and potentials of possible uses, the frequent prejudices of society against industrial architecture can be erased and involved in the programs and help the region to develop. Above all, with a sensitive and systematic approach, it is important to pay attention to preserving the values of the original, which can strengthen the local identity. Focusing on the restoration of the preserved industrial heritage, its revitalization in relation to the environment with a characteristic landscape relief and nature, which can increase the interest of society and especially the quality of life in the region.

The aim of the research was to verify the qualities of historical architecture and whether the objects of industrial heritage can be actively involved in the revitalization process of society in the region. Positive social and economic effects of heritage revitalization in the local context are thus dependent on the involvement of the local community. The material presented does not complete the theoretical and practical aspects of the considered issues, but it reflects the positive changes that took place after pointing out the importance of saving the architecture and the social interest in participating in activities related to its revitalization. At the same time, it is necessary to monitor the area in the future and record changes and impacts on the region in the case of traffic and gradually evaluate how these activities revive the region and as interest in traffic and job opportunities increases. Appropriately chosen proposed function and attentive approach to the restoration and presentation of the several historical objects and localities of this industrial heritage, the currently overlooked area in the region along the main road can become an interesting cultural and social place strengthening the region's identity, its competitiveness, as well as to improve the socio-economic conditions of its inhabitants.

\section{References}

Alberty, J. (1982). Pohorelské železiarne (1807-1826) [Pohorelá ironworks (1807-1826)]. Martin: Vydavatel’stvo Osveta. 512.

Aschenbrierová, V. (2020). Potenciál zaniknutých historických urbanistických štruktúr v kontexte rozvoja regiónu [The potencial of extinct historic urban structures in the context of the development of the region]. In Bardkontakt 2020: Zborník z konferencie s medzinárodnou účast'ou. Bardejov: Mesto Bardejov. 120-129.

Banskobystrický samosprávny kraj (2021) Integrovaná územná stratégia BBSK na roky 2021-2027. [Integrated strategy of Banská Bystrica Self-Governing Region 2021-2027]. Retrieved from https://www.bbsk.sk/\%C3\%9Arad/Organiza\%C4\%8Dn\%C3\%A9jednotky\%C3\%9AraduBBSK/Oddeleniestrat\%C3\%A9gi\% C3\%ADaanal\%C3\%BDz/Integrovan\%C3\%A1\%C3\%BAzemn\%C3\%A1strat\%C3\%A9giaBBSKnaroky2021-2027.aspx

Belláková, E. (2018). Architektúra historických železiarní na Slovensku 1815-1948. [Architecture of historic iron works in Slovakia 1815-1948]. Bratislava: Eurostav.

Cudny W. (2017). The Ironbridge Gorge Heritage Site and its local and regional functions. In: Chodkowska-Miszczuk, J. and Szymańska, D. editors, Bulletin of Geography. Socio-economic Series, No. 36, Toruń: Nicolaus Copernicus University. $61-75$.

Ćurčić, N., Garača, V., Vukosav, S., Bradič, M. (2015). Regeneration of Industrial Heritage in Terms of Sustainable Tourism Development. Retrieved from http://dx.doi.org/10.18509/GBP.2015.60. 471-478 
EESC. (2005). The contribution of tourism to the soci-economic recovery of areas in decline (Declaration of Cordoba). Brussels: 2005

Erih.net. (2021). World Heritage Site Woelklingen Iron Works. [online]. Retrieved from https://www.erih.net/about-erih

Fil'ová, T. (2021). Manažment vybraných kultúrnych trás na Slovensku [Management of selected cultural routes in Slovakia]. Master thesis. Banská Bystrica: Matej Bel University. Faculty of Economics, Department of tourism.

Fragner, B. 2013. Charta prümyslového dědictví TICCIH: Překlad charty TICCIH 2003. ISBN 978-80-01-05235-8.

Greschner, J., Samek, B., \& Starke, J. Š. (1990). 150 rokov železiarní v Podbrezovej [150 years of ironworks in Podbrezova]. Martin: Osveta. 9.

Holec, R. (2010). Coburgovci a Slovensko. [The Coburgs and Slovakia]. Bratislava: Kalligram.

ICOMOS-TICCIH (2011). Principles for the Conservation of Industrial Heritage Sites, Structures, Areas and Landscapes.

The Dublin Principles [online]. Paris: 2011. Retrieved from https://ticcih.org/wp-

content/uploads/2013/10/GA2011_ICOMOS_TICCIH_joint_principles_EN_FR_final_20120110.pdf

Jančura, P. (2005). Európsky dohovor o krajine. [European Landscape Convention]. Banská Bystrica: Slovenská agentúra životného prostredia. ISBN 80-88850-74-6. s. 36

Král'ová, E. (2011). Kultúrne dimenzie brownfieldov. [Cultural dimensions of brownfields]. In: Urbanita. 2013. No. 23/3 ISSN 0139-5912. 8-16

Kupec Architekti. (2019). Coburgovská železná cesta Horehroním [The Coburg Ironworks Route Across Horehronie]. Complex study. Brezno.

Mackovičová, K. (2018). Kultúrne dedičstvo ako súčast' územného kapitálu. [Cultural heritage as part of the territorial capital] Dissertation. Bratislava: ÚM USTU, 2018. 169 s.

Mackovičová, K., Králová, E. (2017). Industriálne dedičstvo - súčast' územného kapitálu. [Industrial heritage - part of territorial capital]. In Bardkontakt 2017: Zborník prednášok 2017: Pamiatky a pamiatkové územia v rozvojových programoch obcí a regiónov. Bardejov: Mesto Bardejov. ISBN 978-80-972776-7-3. 76-85.

Muzej železniki. (2018). Svet pod Ratitovcem. [The land beneath Ratitovec]. Information leaflet. Železniki: Javni závod Ratitovec.

Oevermann, H., Mieg, H. 2015. Transformation of Industrial Heritage sites: Heritage and Planning. In Industrial Heritage Sites in Transformation. New York: Routledge, 2015. ISBN 978-0-415-74528-4, s. 3-11

Šarudyová, M. (1989). Topografia železiarni na Slovensku v 19. storočí. [The Topografy of Iron Works in Slovakia in the 19th Century]. Košice: Východoslovenské vydavatel'stvo Košice. 172-189.

Stašáková, G., Kulla, M. (2016). Pamiatky industriálního dedičstva a ich význam pre rozvoj cestovného ruchu na Slovensku [Industrial heritage monuments and their importance for the development of tourism in Slovakia]. In Geographia cassoviensis X. [cit. 2021-03-20]. Retrieved from https://uge-old.science.upjs.sk/images/geographia_cassoviensis/articles/GC-2016-102/Stasakova_Kulla.pdf

TICCIH., (2003). The Nizhny Tagil Charter for the Industrial Heritage. The International Committee for the Conservation of the Industrial Heritage (TICCIH). Moscow: 2003. [online]. Retrieved from https://ticcih.org/wpcontent/uploads/2013/04/NTagilCharter.pdf

Územná agenda 2020. (2011). Územná agenda Európskej Únie 2020: Smerom k inkluzívnej, inteligentnej, a udržatelnej Európe rozmanitých regiónov. [Territorial Agenda of the European Union 2020: Towards an Inclusive, Smart and Sustainable Europe of Diverse Regions].

Weis, K. (2007). Slovenská banská cesta - SBC . [Slovak Mining Route]. [online]. Retrieved from http://www.slovenskabanskacesta.sk/

Železnácesta. (2021). Slovenská železná cesta. [online]. - [cit. 2018-05-18] Retrieved from http://www.zeleznacesta.sk/index.html 